\title{
Impeded Interaction between Schwann Cells and Axons in the Absence of Laminin $\alpha 4$
}

\author{
Wilhelm Wallquist, ${ }^{1}$ Stefan Plantman, ${ }^{1}$ Sebastian Thams, ${ }^{1}$ Jill Thyboll, ${ }^{2}$ Jarkko Kortesmaa, ${ }^{2}$ Jan Lännergren, ${ }^{3}$ \\ Anna Domogatskaya, ${ }^{2}$ Sven Ove Ögren, ${ }^{1}$ Mårten Risling, ${ }^{1,4}$ Henrik Hammarberg, ${ }^{1,5}$ Karl Tryggvason, ${ }^{2}$ and \\ Staffan Cullheim ${ }^{1}$ \\ Departments of ${ }^{1}$ Neuroscience, ${ }^{2}$ Medical Biochemistry and Biophysics, and ${ }^{3}$ Physiology and Pharmacology, Karolinska Institute, 17177 Stockholm, \\ Sweden, ${ }^{4}$ Department of Defense Medicine, Swedish Defense Research Agency, 17177 Stockholm, Sweden, and 5 Department of Hand Surgery, Stockholm \\ Söder Hospital, 11887 Stockholm, Sweden
}

The Schwann cell basal lamina (BL) is required for normal myelination. Loss or mutations of BL constituents, such as laminin-2 $(\alpha 2 \beta 1 \gamma 1)$, lead to severe neuropathic diseases affecting peripheral nerves. The function of the second known laminin present in Schwann cell BL, laminin-8 ( $\alpha 4 \beta 1 \gamma 1)$, is so far unknown. Here we show that absence of the laminin $\alpha 4$ chain, which distinguishes laminin-8 from laminin-2, leads to a disturbance in radial sorting, impaired myelination, and signs of ataxia and proprioceptive disturbances, whereas the axonal regenerative capacity is not influenced. In vitro studies show poor axon growth of spinal motoneurons on laminin-8, whereas it is extensive on laminin-2. Schwann cells, however, extend longer processes on laminin-8 than on laminin-2, and, in contrast to the interaction with laminin-2, solely use the integrin receptor $\alpha 6 \beta 1$ in their interaction with laminin-8. Thus, laminin- 2 and laminin- 8 have different critical functions in peripheral nerves, mediated by different integrin receptors.

Key words: myelin; extracellular matrix; Schwann cells; electron microscopy; neuropathy; regeneration

\section{Introduction}

Laminins are heterotrimeric glycoproteins composed of one $\alpha$, one $\beta$, and one $\gamma$ chain. So far five $\alpha$, three $\beta$, and three $\gamma$ chains are known, composing at least 14 different laminin isoforms (Libby et al., 2000). In addition to laminin, type IV collagen, perlecan, and nidogen/entactin are among the main protein constituents of basement membranes. Laminins interact with cell surface receptors, leading to intracellular signaling and cytoskeletal reorganization, and thus have important regulatory roles. They appear to participate in Schwann cell migration, differentiation, and myelination (McGarvey et al., 1984; Anton et al., 1994). Also, laminin substrates are known to mediate cell attachment and to promote neurite extension from central as well as peripheral neurons (for review, see Sephel et al., 1989). Laminins also modulate the activities of neurotrophic factors, regulate expression of transmitter enzymes, and have a number of effects on the differentiation of neurons, not mimicked by other ECM glycoproteins (Acheson et al., 1986; Kalcheim et al., 1987). Absence of laminin-2 $(\alpha 2 \beta 1 \gamma 1)$, one of the major proteins in the peripheral nerve basal lamina, leads to merosin-deficient congenital muscular dystrophy (MDCMD) (Xu et al., 1994; HelblingLeclerc et al., 1995). This dystrophy is often severe, progressive,

Received July 22, 2004; revised Feb. 21, 2005; accepted Feb. 22, 2005

This work was supported by the Swedish Medical Research Council (Project 6815), the Marcus and Amalia Wallenberg's Memory Fund, the Marianne and Marcus Wallenberg's Foundation, and the Karolinska Institute.

Correspondence should be addressed to Dr. Wilhelm Wallquist, Department of Neuroscience, Retzius väg 8 B3:3, Karolinska Institute, S-171 77 Stockholm, Sweden. E-mail: wilhelm.wallquist@neuro.ki.se.

D01:10.1523/JNEUROSCI.5225-04.2005

Copyright $\odot 2005$ Society for Neuroscience $\quad$ 0270-6474/05/253692-09\$15.00/0 and accompanied by neurological deficits in both the peripheral nervous systems and CNSs (Jones et al., 2001). In patients with MDCMD and also in laminin $\alpha 2$ knock-out mice, the peripheral nerves display severe dysmyelination, lack of basal lamina, and axon degeneration (Xu et al., 1994; Helbling-Leclerc et al., 1995; Nakagawa et al., 2001).

In a previous study we have shown that the endoneurial basal lamina of peripheral nerves not only contains laminin-2 $(\alpha 2 \beta 1 \gamma 1)$ but also laminin-8 ( $\alpha 4 \beta 1 \gamma 1)$ (Wallquist et al., 2002). Considering the profound effects of laminin-2 deficiency and the importance of basal lamina proteins for cellular interactions, it is of obvious importance to elucidate the function of laminin- 8 in the peripheral nerve. Such information can be gained by studying laminin $\alpha 4$ gene-deleted mice. Previous phenotypic analysis of these animals has shown diffuse subcutaneous hemorrhages in the soft tissues of the hindlimbs, head, lower back, and neck regions during the embryonic and neonatal period and also extensive bleeding and deterioration of microvessel growth in experimental angiogenesis (Thyboll et al., 2002). Moreover, active zones and junctional folds in the skeletal neuromuscular junction are not precisely apposed to each other, although they are formed in normal numbers (Patton et al., 2001). Here we provide data demonstrating extensive morphological changes in peripheral nerves combined with neurological functional deficits in the laminin $\alpha 4$ gene-deleted mouse and that the receptor for laminin- 8 is most probably the $\alpha 6 \beta 1$ integrin.

\section{Materials and Methods}

Animals. Mice lacking laminin $\alpha 4$ were produced by replacement of the promoter and first two coding exons of the lama4-/- gene with a neo- 
mycin resistance gene, using homologous recombination in embryonic stem cells (Thyboll et al., 2002). After germline transmission of the mutant allele, heterozygotes, which displayed no detectable abnormalities, were backcrossed to $\mathrm{C} 57 \mathrm{BL} / 6$ mice for 10 generations, then crossed to generate homozygotes. Lama4-/- mice, which lacked laminin- $\alpha 4$ mRNA and protein, were born at normal Mendelian frequencies. They displayed hemorrhages at birth (Thyboll et al., 2002), but matured normally and were fertile as adults. Phenotypes of two independently derived lines were similar. Wild-type (wt) C57BL/6 mice were used as controls.

Behavioral analysis. Mutant and wild-type controls were examined using the SHIRPA protocol for behavioral analysis (Rogers et al., 1999). The swim test was performed in a $50 \times 30 \mathrm{~cm}$ bowl filled with lukewarm water at a level where the animals were unable to reach the bottom of the bowl. Eight animals in both groups were observed for $60 \mathrm{~s}$ each. In addition, the animals were observed while lifted into the air by the tail and while walking. To assess motor behavior, the hindpaws were dipped in Indian ink, and the animals were allowed to walk $\sim 60 \mathrm{~cm}$ on a paper sheet. The distance between the right and left paw was measured as the step length. To test spasticity, an electromechanical approach was used. The left hindpaw of the mice was fixed to an electromechanical transducer, and the hindleg was flexed and extended six times. The mean amplitude of the tracings, recorded over time, was used as a measurement of the force required to flex or extend the leg.

Morphological analysis of peripheral nerves and CNS. The mice were killed with an overdose of pentobarbital, and the adult mice were transcardially perfused with $15 \mathrm{ml}$ of Tyrode's solution at $20^{\circ} \mathrm{C}$, followed by 20 $\mathrm{ml}$ of a solution containing $2.5 \%$ glutaraldehyde in $0.1 \mathrm{M}$ PBS, $\mathrm{pH} 7.4$. The sciatic nerves, spinal roots, the dorsal column of the spinal cord, and the corpus callosum were dissected out, postfixed with osmium tetroxide (2\%), buffer-rinsed, and alcohol-dehydrated for embedding in Durcupan (Fluka, Chemie, Buchs, Switzerland). Transverse semithin $(0.5 \mu \mathrm{m})$ sections were obtained and stained with toluidine blue for light microscope analysis. Ultrathin sections were then obtained for ultrastructural analysis. Neonatal mice $(0,6$, and $12 \mathrm{~d}$ old $)$ were not perfused, but the specimens were fixed after dissection in the glutaraldehyde solution overnight and otherwise treated in the same way as specimens from adult mice. Sciatic nerves of uninjured adult mice as well as after 6 weeks and 5 months of regeneration after a crush lesion were studied. Axon area, circumference, and myelin thickness of 500 axons per slide was measured on semithin sections using a PL-APO objective in a Leica (Wetzlar, Germany) DM RBE microscope and digitized at a final linear magnification of $6700 \times$ using a Kappa video camera (Mikroskop System, Näsviken, Sweden) and a Perceptics PixelBuffer (Parameter, Stockholm, Sweden) image grabber card. The measurements were made with NIH Image software (version 1.55; National Institutes of Health, Bethesda, MD).

Regeneration rate in the sciatic nerve. The sciatic nerve was crushed below the sciatic notch, and the lesion was marked with an 8-0 ethilon suture (Johnson \& Johnson, Sollentuna, Sweden). The nerves were allowed to regenerate for $3 \mathrm{~d}$ and thereafter treated according to two different protocols. Either a new crush was performed $\sim 3 \mathrm{~mm}$ proximal to the first lesion under isoflurane anesthesia, and neurobiotin tracer (Vector Laboratories, Burlingame, CA) was injected into the second crush or the mice were killed without further surgery. In the case in which the mice had another crush lesion, they were killed after $5 \mathrm{hr}$. All mice were killed by an overdose of pentobarbital ( $\sim 20 \mathrm{mg} / 100$ g; Pentobarbitalnatrium; Apoteksbolaget, Stockholm, Sweden) and perfused transcardially with $15 \mathrm{ml}$ of Tyrode's solution at $20^{\circ} \mathrm{C}$, followed by $20 \mathrm{ml}$ of fixative at $20^{\circ} \mathrm{C}$ containing $4 \%$ formaldehyde and $0.4 \%$ picric acid in 0.16 м phosphate buffer, $\mathrm{pH} 7.2$. The sciatic nerves were quickly dissected out. The specimens were immersion-fixed for $2-3 \mathrm{~h}$ at $4^{\circ} \mathrm{C}$ and transferred into a 0.01 м PBS solution containing $0.1 \%$ sodium azide (Sigma, St. Louis, $\mathrm{MO}$ ) and stored at $4^{\circ} \mathrm{C}$. One day before sectioning, the tissue was transferred into $0.01 \mathrm{~m}$ PBS containing $10 \%$ sucrose and $0.1 \%$ sodium azide. The specimens were stored overnight at $4^{\circ} \mathrm{C}$. The specimens were cut in a cryostat (Microm, Heidelberg, Germany) at $10 \mu \mathrm{m}$ thickness. Sections of nerves traced with neurobiotin tracer were incubated at room temperature with streptavidin cyanine 3 (Cy3) fluorescent marker (Jackson ImmunoResearch, West Grove, PA).

The other sections were stained with polyclonal antibody to
neurofilament-H (200 kDa; C terminus; antibody 1989; Chemicon, Temecula, CA), galanin, and calcitonin gene-related peptide (CGRP) (Peninsula Laboratories, Belmont, CA). The slides were incubated with primary antibodies overnight at $4^{\circ} \mathrm{C}$. After three $5 \mathrm{~min}$ rinses in $0.01 \mathrm{~m} \mathrm{PBS}$, the sections were incubated for $1 \mathrm{~h}$ at room temperature with $\mathrm{Cy} 2-$ conjugated donkey anti-rabbit (1:200; Jackson ImmunoResearch).

After rinsing in PBS, all sections were mounted in a mixture of PBS and glycerol (1:3) containing $0.1 \%$ p-phenylenediamine to prevent fading of immunofluorescence. Sections were examined in a Leica DM RBE microscope equipped with epifluorescence and appropriate filter combinations for the fluorophores used here (Leica). The distance between the lesion site and the axonal growth front was measured using a PL-APO objective in a Leica DM RBE microscope (Leica) and digitized at a final linear magnification of $400 \times$ using a Kappa (Mikroskop System) video camera and a Perceptics PixelBuffer (Parameter) image grabber card. The measurements were made with NIH Image software (version 1.55; National Institutes of Health).

Cell cultures. Cultures of purified embryonic motoneurons were prepared with an immunopanning procedure, first described by Henderson et al. (1993) and Camu and Henderson (1992). The protocol used in this study was adopted from Hughes et al. (1993), Piehl et al. (1995), and Hanson et al. (1998) with modifications according to Hammarberg et al. (2000b). Briefly, spinal cords from embryonic day 15 Sprague Dawley rat embryos (BK Universal) were taken out and dissected free of meninges. The lumbar segments of the ventral columns were cut clean from the dorsal parts, and the floor plate was trypsinized and dissociated. The resulting cell suspension was separated by centrifugation on a metrizamide $(6.5 \mathrm{mg} / \mathrm{ml}$; Sigma $)$ density gradient. Large, low-density cells were collected and further enriched by immunopanning. The cell suspension was panned onto an immobilized monoclonal antibody layer derived from a mouse hybridoma (MC192, protein-A purified, $2.5 \mu \mathrm{g} / \mathrm{ml}$; generously supplied by Drs. Eric Shooter and Ben Barres, Stanford University, Stanford, CA) (Chandler et al., 1984). The antibody is directed against the low-affinity nerve growth factor receptor [protein of $\sim 75 \mathrm{kDa}$ (p75)], which is highly expressed by motoneurons at this developmental stage (Yan and Johnson, 1988). Free-floating cells were washed away, and antibody-bound motoneurons were subsequently released by addition of a 10-fold excess of MC192 antibody. The cells were collected and plated onto cell culture dishes (4-well; $10 \mathrm{~mm}$; Greiner Bio-One International AG, Kremsmuenster, Austria) precoated with poly-DL-ornithine (0.5 $\mu \mathrm{g} / \mathrm{ml}$ in $0.15 \mathrm{M}$ sodium boric acid) and Engelbreth-Holm-Swarmlaminin (10 $\mu \mathrm{g} / \mathrm{ml}$; Sigma), collagen-1 (Invitrogen, San Diego, CA), laminin-2 (Chemicon), laminin-8 (Kortesmaa et al., 2000), or laminin-10 (Doi et al., 2002) at a density of 200-300 neurons $/ \mathrm{cm}^{2}$ in serum-free medium: Neurobasal or bicarbonate-buffered Leibovitz L-15 with glucose $4 \mathrm{~g} / \mathrm{l}$ and penicillin-streptomycin, supplemented with transferrin $100 \mu \mathrm{g} / \mathrm{ml}$, insulin $3 \mu \mathrm{g} / \mathrm{ml}$, progesterone, putrescine, and sodium selenite, and in some cases addition of $2 \%$ horse serum and trophic factors. Recombinant laminin-8 was produced in human embryonic kidney cells (HEK-293; catalog \#CRL-1573; American Type Culture Collection, Manassas, VA). Cells were stably transfected with the mouse laminin $\beta 1$ expression construct and selected using G418 (Invitrogen). A highly expressing clone was then transfected using the calciumphosphate method with $\alpha 4-N$-Asp-Tyr-Lys-Asp-Asp-Asp-Asp-Lys-(C) (FLAG) construct, and stable colonies were selected using $300 \mu \mathrm{g} / \mathrm{ml}$ Zeocin (Cayla). Clones were isolated, expanded, and analyzed for lami$\operatorname{nin} \alpha 4$ secretion by Western blotting. The selected clone was transfected with the human laminin $\gamma 1$ construct, and stable clones were selected using hygromycin (Cayla). Cells were grown for up to $4 \mathrm{~d}$, after which the medium was collected. Laminin-8 was affinity-purified using anti-FLAG M2 matrix (Sigma). Before use, the matrix was washed according to the manufacturer's instructions. Brij-20 (Fluka Chemie) was added to the collected medium followed by incubation with the matrix overnight at $+4^{\circ} \mathrm{C}$ with agitation. The matrix was collected in a column, washed, and bound laminin-8 was eluted with FLAG peptide (Sigma) in PBS. Further purification was performed using a UNO-Q ion-exchange column (BioRad, Hercules, CA). Finally, the eluate was concentrated using $100 \mathrm{kDa}$ cutoff ultrafiltration (Gelman). Laminin-10 was produced essentially as described for the production of laminin-8. Human embryonic kidney 
cells were transfected using the calcium-phosphate method with the human laminin $\gamma 1$ and human laminin $\beta 1$ constructs. A clone highly expressing both laminin $\gamma 1$ and laminin $\beta 1$ was finally transfected with the human laminin $\alpha 5$-FLAG construct. Laminin-10 was affinity-purified using anti-FLAG M2 matrix (Sigma). The eluate was concentrated, and the buffer was replaced by PBS using $30 \mathrm{kDa}$ cutoff ultrafiltration (Millipore, Bedford, MA). Finally, the concentrated solution was passed through a $0.2 \mu \mathrm{m}$ filter to remove self-aggregated polymers. Neurobasal and L15 medium were obtained from Invitrogen, and the remaining agents were from Sigma. The cells were cultured for $3 \mathrm{~d}$ in a humidified chamber at $37^{\circ} \mathrm{C}$ with $5 \% \mathrm{CO}_{2}$. New media and factors were added once a day.

The purity of the cultures was evaluated with neuron-specific antibodies, neuron-specific nuclear protein $(\mathrm{NeuN})$, microtubule-associated protein (MAP-2) (clone HM-2; Sigma) (Caceres et al., 1984), motoneuron-specific antibodies against Islet-1 (mouse, IgG, clone 2D6; Developmental Studies Hybridoma Bank) (Ericson et al., 1992), and low-affinity neurotrophin receptor (p75, clone MC 192) and found to be $>95-99.5 \%$ MAP-2-positive and NeuN-positive cells, 90-95\% p75positive, and $84-90 \%$ Islet-1-positive which suggests that also the contamination of nonmotoneuronal neurons was small.

Preparation of Schwann cells. Rat pups [postnatal day 4 (P4)] were anesthetized with carbon dioxide and decapitated. The sciatic nerves were removed under aseptic conditions and stored in calcium- and magnesium-free (CMF) PBS, on ice. Nerves were freed of contaminating tissue, washed twice in PBS, and teased apart. After this, the teased nerves were incubated in $0.2 \%$ collagenase (Sigma) in CMF HBSS at $37^{\circ} \mathrm{C}$ for 30 min. To this solution, trypsin (Sigma) was added to a final concentration of $0.125 \%$ followed by incubation for $20 \mathrm{~min}\left(37^{\circ} \mathrm{C}\right)$. Enzymatic activity was stopped by the addition of fetal bovine serum (to a final concentration of $\sim 15 \%$ ), and finally DNase (Invitrogen) was added. Nerves were dissociated by gentle shaking for $2 \mathrm{~min}$ followed by two or three triturations using a flame-polished Pasteur pipette. The cell suspension was centrifuged through a $4 \%$ bovine serum albumin (BSA) cushion (1200 $\mathrm{rpm}, 10 \mathrm{~min}$ ), the supernatant was removed, and the pellet was dissociated in prewarmed medium. Cells were preplated for $2 \mathrm{~h}$ (to allow reexpression of surface proteins cleaved by trypsin and to remove the majority of contaminating fibroblasts), and nonadherent cells were collected, centrifuged, and resuspended in medium.

Purity of Schwann cells. The purity of the preparation was assessed using immunostaining with antibodies raised against S-100 $\beta$ (DakoCytomation, Glostrup, Denmark) to label Schwann cells and Thy1.1 (Cedarlane, Hornby, Ontario, Canada) to label fibroblasts, and secondary antibodies conjugated to $\mathrm{Cy} 2$ and $\mathrm{Cy} 3$ to distinguish between the two. Cells were counted under fluorescent illumination with the appropriate filter setting. The purity of Schwann cells obtained by the procedure described above was $\sim 95 \%$.

Adhesion assay. Schwann cell adhesion was assessed by coating small areas of an untreated $100 \mathrm{~mm}$ Petri dish (Corning, Acton, MA), with PBS containing $10 \mu \mathrm{g} / \mathrm{ml}$ laminin-2 (Chemicon), laminin-8 (Kortesmaa et al., 2000), collagen (Invitrogen), fibronectin (10 $\mu \mathrm{g} / \mathrm{ml})$ (Sigma), polyD-lysine (PDL) (Sigma), or PBS. Dishes were coated for $2 \mathrm{~h}$ in $37^{\circ} \mathrm{C}$ and blocked with $0.3 \%$ BSA for 30 min before adhesion of cells. Schwann cells were added in $50 \mu \mathrm{l}$ drops at a concentration of $\sim 20 \times 10^{6}$ cells $/ \mathrm{ml}$, left to adhere for $1 \mathrm{~h}$ in $37^{\circ} \mathrm{C}$. Nonadherent cells were washed away, and the cells were fixed for $20 \mathrm{~min}$ in $4 \%$ paraformaldehyde, rinsed, and counted under inverted microscope. For each area, a minimum of two grids were counted, and during each experiment, five areas were counted, the values represent the average \pm SEM of three such experiments.

For blocking experiments, cells were incubated with antibodies against integrin $\alpha 6$ (clone GOH3; Santa Cruz Biotechnology, Santa Cruz, CA), integrin $\beta 1$ (anti-CD29; BD Biosciences, San Jose, CA), and integrin $\beta 4$ (anti-CD104; Chemicon). Anti- $\alpha 6$ and anti- $\beta 1$ antibodies were used at a concentration of $10 \mu \mathrm{g} / \mathrm{ml}$. Anti- $\beta 4$ was tested at 5,10 , and $30 \mu \mathrm{g} / \mathrm{ml}$. To block RGD-interacting integrins, echistatin (Sigma) was tested at 1 and 5 $\mu \mathrm{M}$. Blocking agents were added at the final wash and present during the adhesion phase.

Migration assay. Schwann cells were obtained as previously described and resuspended at a concentration of $\sim 50 \times 10^{6}$ cells $/ \mathrm{ml}$ in Neurobasal

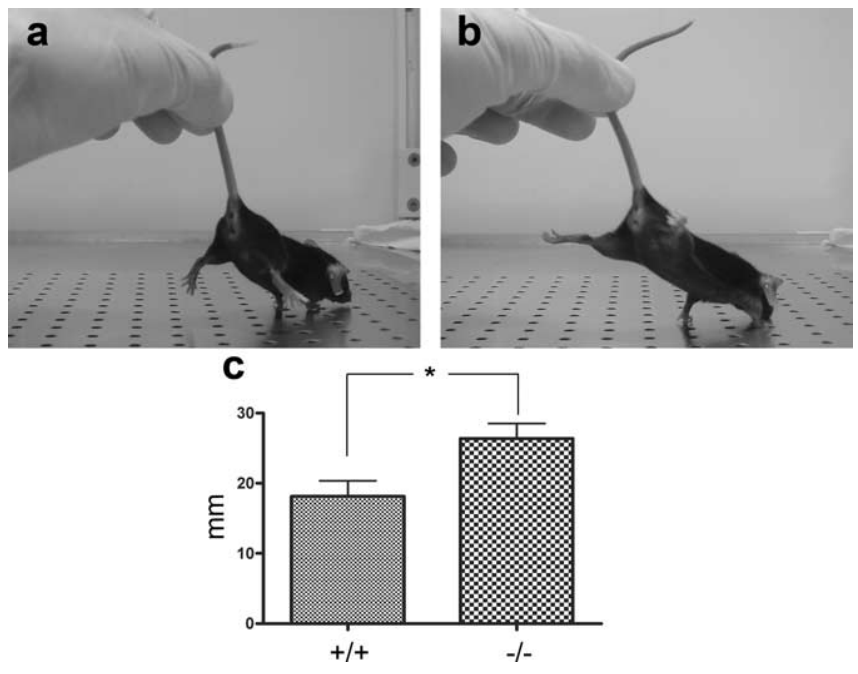

Figure 1. Behavioral testing of the laminin $\alpha 4$ knock-out mouse. While holding the mice by the tail, mutant mice had a tendency to extend their legs backward with the paws turned upside down in a spastic-like manner $(\boldsymbol{b})$. This was never observed in wild-type mice $(\boldsymbol{a})$. The mice were able to walk seemingly normally, but a closer observation revealed a greater variation in step length of mutant mice, measured as the difference between the longest and shortest step, suggesting ataxia (c).

medium with B27 supplement (NBB27) with 50\% Growth Factor Reduced Matrigel (Invitrogen). One drop of $1.5 \mu$ l was added to each well in 4-well dishes (Cellstar, Greiner, Germany). The dishes were incubated for $15 \mathrm{~min}$ at $37^{\circ} \mathrm{C}$, to allow the Matrigel to set. After this, $50 \mu$ l of NBB27 medium containing $10 \mu \mathrm{g} / \mathrm{ml}$ of laminin-2 (Chemicon), laminin-8 (Kortesmaa et al., 2000), and PDL (Sigma) was added to each well. The dishes were incubated for $2 \mathrm{~h}$. Thereafter $1.5 \mathrm{ml}$ of medium was added to each dish, and the cells were cultured at $37^{\circ} \mathrm{C}, 5 \% \mathrm{CO}_{2}$. The distance from the edge of the drop to the leading edge of the migrating cells was measured on four sides of the drop, on daily intervals.

Morphological analysis. Cultures used in the adhesion study were immunolabeled with antibodies raised against S-100 $\beta$ (DakoCytomation) and Cy2-conjugated secondary antibodies. The length of the longest process was measured using a PL-APO objective in a Leica DM RBE microscope (Leica) and digitized at a final linear magnification of $6700 \times$ using a Kappa video camera (Mikroskop System) and a Perceptics PixelBuffer image grabber card (Parameter). The measurements were made with NIH Image software (version 1.55; National Institutes of Health).

Online supplemental material. Video 1 (available at www.jneurosci.org as supplemental material) shows wild-type mice $(+/+)$ compared with mutant mice $(-/-)$ while swimming in lukewarm water, an experiment done to test the proprioceptive system.

\section{Results}

\section{Behavioral analysis}

Behavioral analysis using the SHIRPA protocol (Rogers et al., 1999) did not reveal any apparent differences between wild-type and mutant mice, except a mild ataxia in mutant mice, evident early in development. This ataxia could be detected in all genedeleted animals in a double-blind setup by observing the hindlimbs of the mice while lifting them in the proximal part of the tail. Initially, this induced a contraction of the hindlimbs toward the trunk, which shortly thereafter was succeeded by an uncoordinated spastic-like extension. This pattern was never seen in wild-type mice. When allowed to place their front paws on a surface, the hindlimbs of mutant mice responded by making a spastic-like extension (Fig. 1). The possibility that increased spasticity could contribute to the altered behavior was tested by use of an electromechanical transducer, which monitored the force required to passively flex or extend the hindlimb (see Materials and 
Methods). No difference between wild-type and mutant mice was seen (data not shown), indicating that an increased spasticity could not explain the disturbed behavior in the mutants.

Another feature of the mutant mice was tremor, evident at rest. There were, however, no disturbances in initiation of movements or performance in simple tasks. Walking was seemingly normal, but when the stride length was measured, a slight ataxia was again revealed. This was seen as a larger variation in step length, measured as the distance between the longest and shortest step, when walking (see Materials and Methods) (Fig. 1). Another impediment observed in the mutant mice was related to their swimming behavior. Placed in water, all animals were able to swim fairly well for a while. All mutant animals had frequent arrests in their swimming, however, some of them lasting $>5 \mathrm{~s}$, when the mice were only floating on the surface of the water or swimming in a profoundly uncoordinated manner (video, available at www.jneurosci.org as supplemental material).

\section{Mice lacking laminin $\alpha 4$ develop a dysmyelinating neuropathy}

The morphology of the mutant and control sciatic nerves was examined by analysis of semithin sections or by electron microscopy. Already at the light microscopic level, pathological changes were evident in adult nerves. Thus, myelin sheaths appeared thinner, and several dysmyelinated areas were found (Fig. $2 b$ ). In these areas, unmyelinated axons of all calibers were grouped in bundles, in an unsorted manner. These bundles were not invested by Schwann cell cytoplasm (Fig. 2d). In some cases, polyaxonal myelination was manifested as bundles of several small axons surrounded by a single myelin sheath (Fig. 2e). Occasionally, large-caliber axons were seen without myelin, Schwann cell cytoplasm, or sometimes even a basal lamina (Fig. 2f). Additionally, several myelinated and unmyelinated axons could be surrounded by a common myelin sheath (Fig. $2 g$ ). The pathological findings were also seen in ventral and dorsal roots (data not shown).

Measurement of myelin thickness [growth ratio (g ratio)] of axons seemingly normally myelinated clearly showed that myelin sheaths in mutant sciatic nerves were thinner than in wild-type animals (mutant g ratio $=0.76 \pm 0.01$ vs wt g ratio $=0.66 \pm 0.02$; $p<0.01 ; n=6$ per group). No difference was seen regarding axon diameter (mean diameter $5.71 \pm 0.31 \mu \mathrm{m}$ in wt and $5.65 \pm$ $0.12 \mu \mathrm{m}$ in mutant mice; $n=6$ per group). Measurement of myelin thickness grouped by axon diameter showed that this difference was seen in both large-diameter and small-diameter axons (Fig. $2 h$ ). No difference was seen in the distribution of axon diameters in wild-type compared with mutant mice (data not shown).

In neonatal animals, no difference was seen at young ages (P0). Most, but not all axons had developed a 1:1 relationship with Schwann cells, and a few had thin myelin sheaths in both wild-type and mutant mice. At P6, however, it was evident that the myelination was well under way in the wild-type mice, whereas mutant nerves displayed axon bundles that were not invested by Schwann cells and had generally thin myelin sheaths. At P12, no apparent difference was seen compared with adult nerves (Fig. 3).

Also the CNS was examined ultrastructurally for abnormalities in myelination. Specimens were taken from adult mutant and wildtype spinal cords (Fig. $4 a, b$ ) and corpus callosum (Fig. $4 c, d$ ). G ratio in spinal cord white matter of wild-type mice was $0.70 \pm 0.01$, and in mutant mice, the ratio was $0.70 \pm 0.01$ ( $p=0.913 ; n=6$ per group). No other obvious differences were seen in the white matter, indicating normal myelination and axonal development.
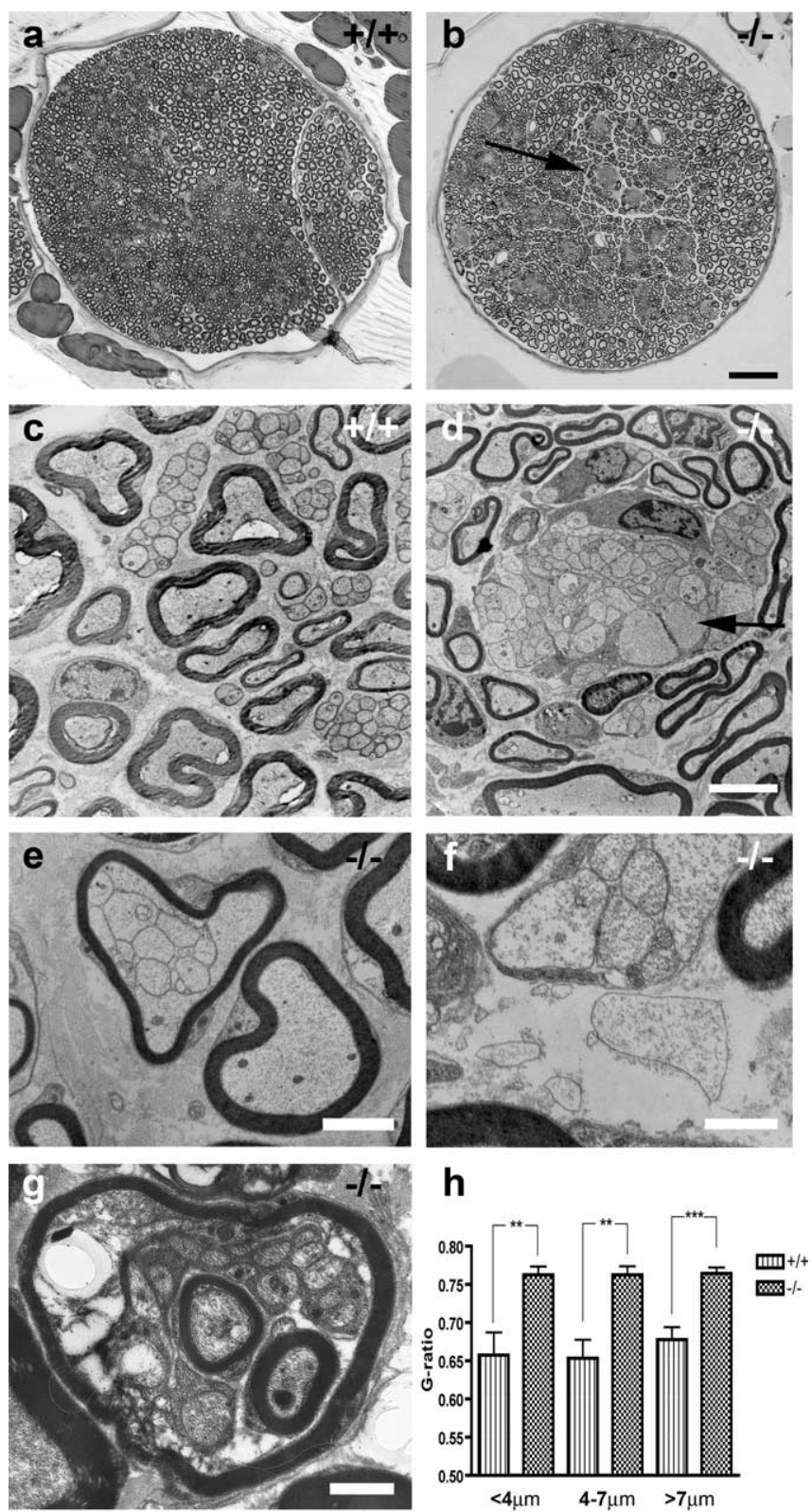

Figure2. Dysmyelination in the sciatic nerve. Light $(\boldsymbol{a}, \boldsymbol{b})$ and electron micrographs $(\boldsymbol{c}-\boldsymbol{g})$ of sciatic nerves from wild-type $(+/+)$ and mutant $(-/-)$ mice. Sciatic nerve from wild-type mouse $(\boldsymbol{a}, \boldsymbol{c})$. Large axons were seen myelinated in a 1:1 relationship. Smaller axons were arranged in small groups and separated by Schwann cell cytoplasm. In mutant mice, bundles of dysmyelinated axons were seen as lighter areas scattered in the nerve ( $\boldsymbol{b}$, arrow). In electron microscopy, large-caliber axons had thinner myelin sheaths than normal and were in some areas seen totally without myelin ( $\boldsymbol{d}$, arrow). In these areas, large-caliber axons were grouped with other unmyelinated axons of various diameters in bundles, in an unsorted manner. These bundles were poorly or not at all invested by Schwann cell cytoplasm. In a few cases, axons were seen without myelin, Schwann cell cytoplasm, or even basal lamina ( $\boldsymbol{d}$, enlargement in $\boldsymbol{f}$ ). Note, however, the intact basal lamina surrounding myelinated axons and most axon bundles in $\boldsymbol{d}-\boldsymbol{g}$, reflecting only moderate defects in the mutant basal lamina. Also, bundles of several small axons were surrounded by a single myelin sheath $(\boldsymbol{e})$ and sometimes even one or more myelinated axons within another myelinated axon $(\boldsymbol{g})$. Graph shows myelin thickness in wild-type and mutant sciatic nerves measured as the $g$ ratio. Bars are grouped by axon diameter $(\boldsymbol{h})$. Scale bars: $\boldsymbol{b}, 50 \mu \mathrm{m} ; \boldsymbol{d}$ (for $\boldsymbol{c}, \boldsymbol{d}), 4 \mu \mathrm{m} ; \boldsymbol{e}, 2 \mu \mathrm{m} ; \boldsymbol{f}, \boldsymbol{g}, 1 \mu \mathrm{m}$.

\section{Effect of nerve crush}

To examine the functional role of laminin $\alpha 4$ during nerve regeneration in adult animals, we measured the number of regenerated and myelinated axons, as well as their axon diameter and myelin 

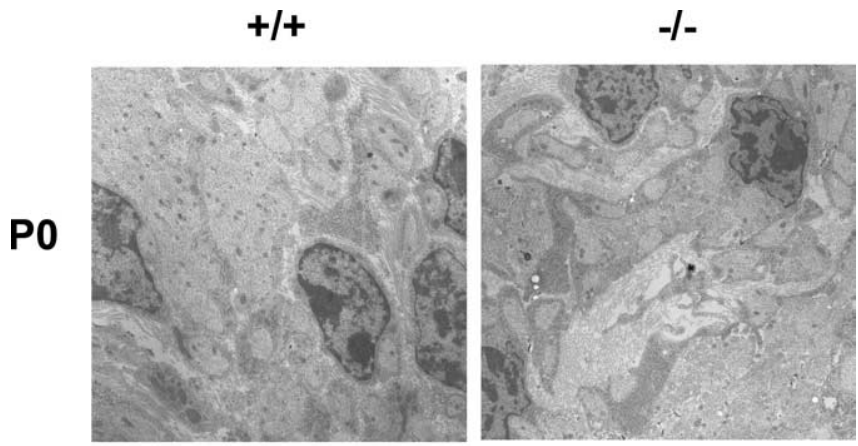

P6
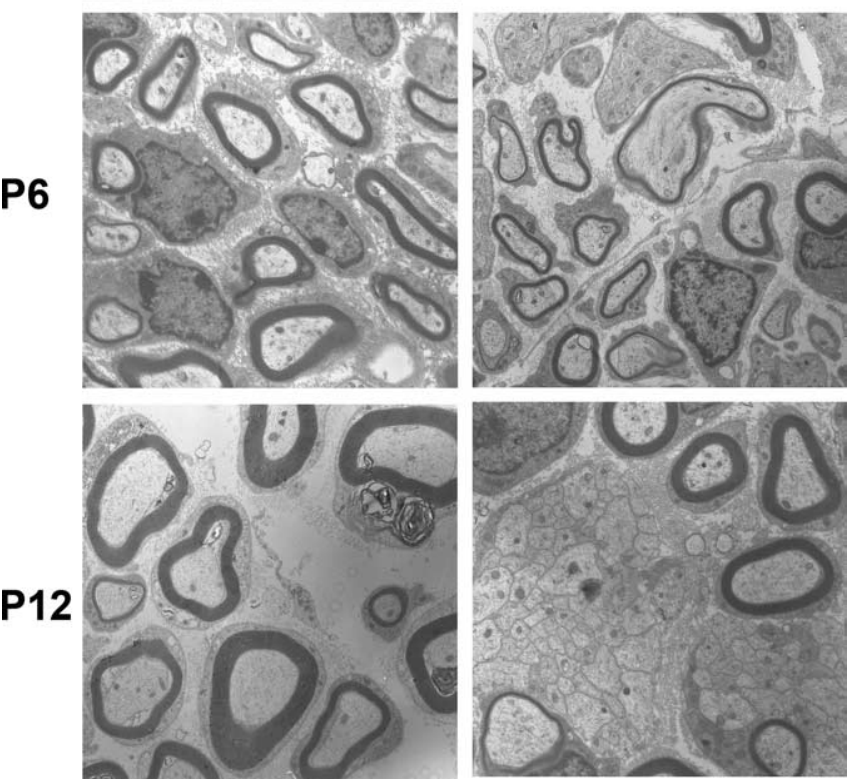

Figure 3. Neonatal development of the sciatic nerve in wild-type and laminin $\alpha 4$-deficient mice. At P0, most axons have a 1:1 relationship with Schwann cells, and a few have thin myelin sheaths in both wild-type and mutant mice. At P6, the myelination was well under way in the wild-type mice, whereas mutant nerves displayed axon bundles that are not invested by Schwann cells and have generally thin myelin sheaths. At P12, the differences seen in adult nerves are established.

thickness 6 weeks and 5 months after a crush injury. No difference between wild-type and mutant mice was seen regarding the number of regenerated axons (wt mean, $4159 \pm 89$ axons per nerve; mutant mice mean, $4195 \pm 125$ axons per nerve; $n=6$ per group). To our surprise, however, the difference in myelin thickness between wild-type and mutant unlesioned animals was not preserved early after regeneration. Thus, 6 weeks after a sciatic nerve crush (SNC), g ratios in mutant and wild-type mice were $0.68 \pm 0.01$ and $0.68 \pm 0.01$, respectively ( $n=6$ per group), which is quite close to the $g$ ratio in uninjured wild-type axons. At this stage, however, the axon diameters were considerably smaller than normal $(4.03 \pm 0.24 \mu \mathrm{m}$ in wt and $3.67 \pm 0.18 \mu \mathrm{m}$ in mutant mice). The difference between wt and mutant mice was not statistically different ( $p=0.2699 ; n=6$ per group). In contrast, 5 months after a sciatic nerve crush, myelin thickness in mutant mice was again thinner compared with wild type. Thus, the $g$ ratio in mutant mice 5 months after SNC was $0.80 \pm 0.01$ compared with $0.73 \pm 0.01$ in wild type $(p<0.001 ; n=3$ per group), indicating that the difference in myelin thickness again was re-established (Fig. 5). Axon diameter measurements revealed that the myelin-free diameter of the axons was not significantly larger compared with the axon diameter 6 weeks after injury $(4.62 \pm 0.28 \mu \mathrm{m}$ in wt and $3.92 \pm 0.05 \mu \mathrm{m}$ in mutant

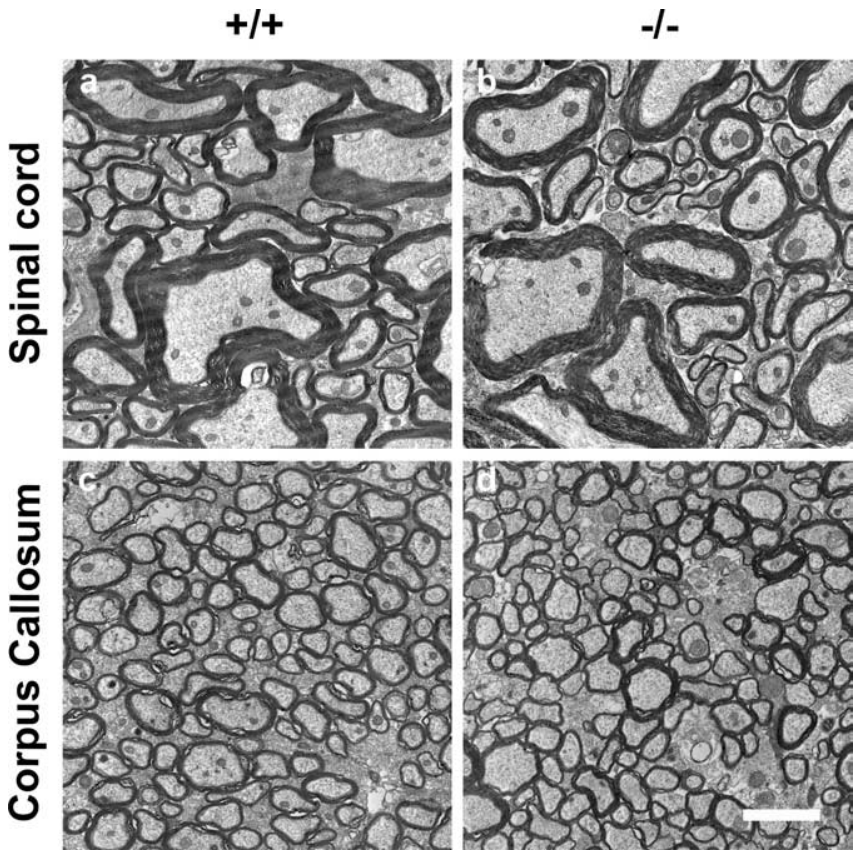

Figure 4. Electron micrographs of uninjured CNS white matter. No difference in the spinal cord dorsal column $(\boldsymbol{a}, \boldsymbol{b})$ and corpus callosum $(\boldsymbol{c}, \boldsymbol{d})$ was seen between wild-type $(\boldsymbol{a}, \boldsymbol{c})$ and mutant $(\boldsymbol{b}, \boldsymbol{d})$ mice. Scale bar: (in $\boldsymbol{d}) \boldsymbol{a}-\boldsymbol{d}, 2 \mu \mathrm{m}$.

mice), indicating a decreased myelin thickness with time in both groups, but more so in mutant mice. The differences between the myelin g ratios in nerves 5 months after crush lesions and axons of corresponding diameter in uninjured nerves were not significantly different in either wild-type or mutant mice, indicating a return to a myelin state more similar to the one seen in uninjured nerves ( $g$ ratio in wild-type mice: $0.66 \pm 0.03, n=6$ in uninjured and $0.73 \pm 0.01, n=3$ in injured; $p=0.1360$; $g$ ratio in mutant mice: $0.76 \pm 0.02, n=6$ in uninjured and $0.80 \pm 0.01, n=3$ in injured; $p=0.0696$ ). The abnormal bundles of axons seen in nerves of uninjured mutant mice were not present at any time after regeneration.

We also compared the regeneration rate in laminin $\alpha 4$ knockout mice after SNC to wild-type control using direct immunofluorescence with neurofilament, galanin, and CGRP antibodies or labeling with an anterograde tracer (see Materials and Methods). No difference was seen between wild-type and mutant mice with either of the techniques $3 \mathrm{~d}$ after SNC. Regeneration rate measured as the average length between lesion site and growth front visualized with neurobiotin tracer was $5027 \pm 296 \mu \mathrm{m}(n=5)$ and $5228 \pm 1098 \mu \mathrm{m}(n=4)$ in wild type and knock-out, respectively.

\section{In vitro assays}

Schwann cells were studied in cultures on different matrix substrates. Difference in adhesion, growth, and migration was seen depending on the substrate used for coating. Both laminin-2 and laminin-8 proved to support Schwann cell adhesion and migration. In the adhesion assay, the number of cells per grid adhered to laminin-2 was $65.56 \pm 4.08 \%$ of the number adhered to PDL, and on laminin- $864.30 \pm 5.19 \%$ of the number adhered to PDL $(n=6 ; p=0.853)$. To test the receptor interaction underlying adhesion, the adhesion assay was performed with antibodies blocking the integrin $\alpha 6, \beta 1$, and $\beta 4$ receptor components, as well as the RGD-blocking substance echistatin. Blocking adhesion with antibodies against integrin $\alpha 6$ did not affect binding to 

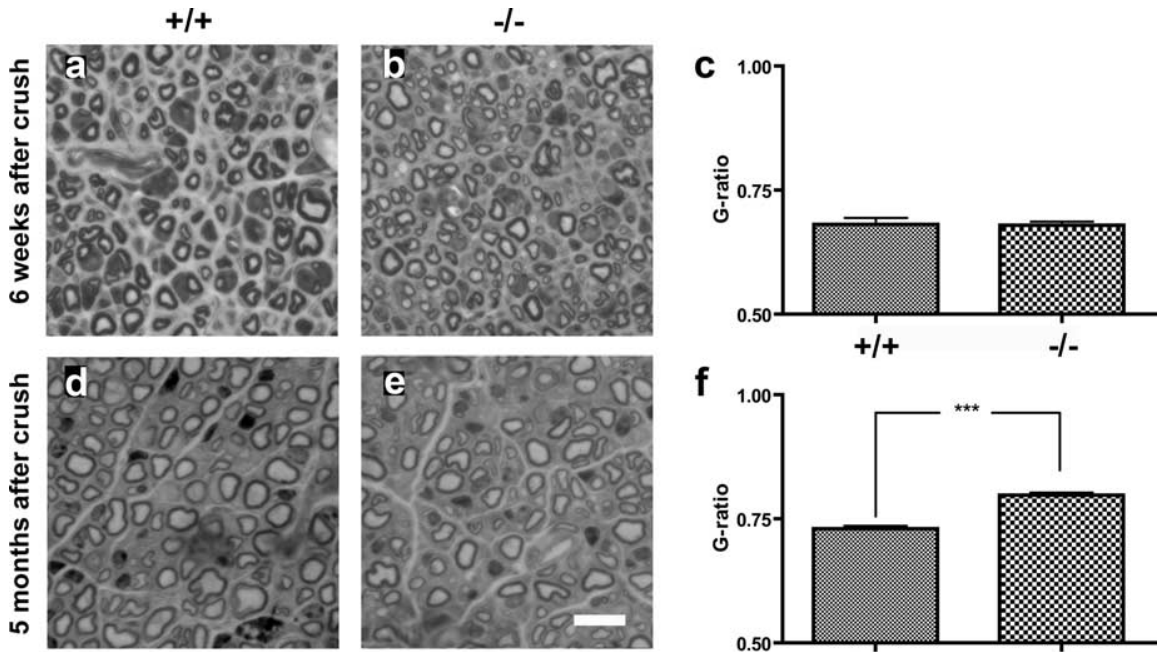

$f$

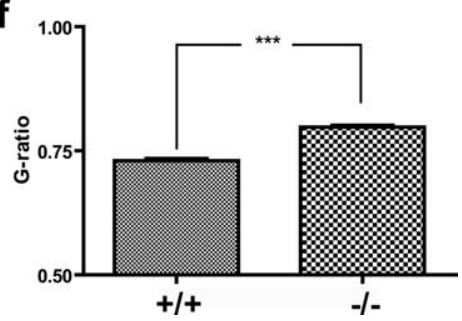

Figure 5. Effects of SNC. Photomicrograph of the sciatic nerves $4 \mathrm{~mm}$ distal to a crush lesion 6 weeks $(\boldsymbol{a}, \boldsymbol{b})$ and 5 months $(\boldsymbol{d}, \boldsymbol{e})$ after SNC. Axons have regenerated and become myelinated 6 weeks after SNC $(\boldsymbol{a}, \boldsymbol{b})$. No difference in myelin thickness is seen between wild-type $(\boldsymbol{a})$ and mutant $(\boldsymbol{b})$ mice, which is shown quantitatively in the graph $(\boldsymbol{c})$. At 5 months after SNC, mutant mice (e) display relatively thinner myelin sheaths compared with wild type $(\boldsymbol{d})$. № abnormal bundles were seen at any time after regeneration. The graph in $\boldsymbol{f}$ is based on quantitative measurements. Scale bar: (in $\boldsymbol{e}$ ) $\boldsymbol{a}, \boldsymbol{b}, \boldsymbol{d}, \boldsymbol{e}, 10 \mu \mathrm{m}$.

laminin-2 (62.45 $\pm 3.55 \%$ of PDL), whereas binding to laminin-8 was almost completely blocked ( $6.22 \pm 1.50 \%$ of PDL) ( $p=0.0001 ; n=3$ per group). Blocking of the $\beta 1$ receptor, however, caused inhibition of adhesion on both laminin- 2 and laminin-8. The RGD sequence-blocking substance echistatin or antibodies against integrin $\beta 4$ did not reduce the binding of Schwann cells to laminin-2 or laminin-8 significantly (laminin-2/echistatin $0.691 \pm 0.0469 \%$, laminin- $2 / \beta 40.733 \pm 0.0503 \%$, laminin- $8 /$ echistatin $0.516 \pm 0.0102 \%$, and laminin- $8 / \beta 40.504 \pm 0.0185 \%$ ) (Fig. 6). Echistatin did block the binding of Schwann cells to fibronectin $(0.493 \pm 0.0479 \%$ compared with $0.138 \pm 0.00842 \% ; p<$ $0.005 ; n=3$ ), however (Fig. 6), indicating that this substance has a receptor-blocking function. Blocking integrin $\beta 4$ did not affect binding to any of the substrates. This was, however, not surprising, because only a subset of the cultured Schwann cells stained positive by use of immunohistochemistry with an integrin $\beta 4$ antibody (data not shown). In support of this, a previous study has shown that the $\alpha 6 \beta 4$ integrin is not expressed until perinatally just before myelination (Previtali et al., 2003b), a stage in which our cells were not. Adhesion of Schwann cells on other substrates as poly-D-lysine was not affected by any of our function-blocking antibodies, indicating that the demonstrated adhesion on laminin-2 and laminin-8 represents specific receptor effects (Fig. 6).

When Schwann cells were allowed to migrate on different substrates for $4 \mathrm{~d}$, no difference was seen in migratory ability between cells cultured on laminin-2 and laminin-8 (Fig. 6). However, the morphology of individual Schwann cells showed significant differences depending on the substrate. Thus, Schwann cells cultured on laminin- 8 were able to extend much longer processes from the cell body than those cultured on laminin-2 $(22.5 \pm 2.5$ and $10.8 \pm 0.3 \mu \mathrm{m}$, respectively; $p<$ $0.05 ; n=3$ per group) (Fig. 7 ).

Also embryonic rat motoneurons were allowed to plate and extend axons on different laminin isoforms (see Materials and Methods). The longest neurites were extended on laminin-2 $(254.1 \pm 25.2 \mu \mathrm{m})$. Also laminin-1 and laminin-10 (Doi et al., 2002) proved to be rather good for axon elongation (194.2 \pm 23.2 and $187.4 \pm 41.8 \mu \mathrm{m}$, respectively). Axon growth on laminin-8 was poor, however $(104.5 \pm 9.3 \mu \mathrm{m})$, and only slightly better than on collagen-1 $(62.5 \pm 1.6 \mu \mathrm{m})$ or BSA $(51.4 \pm 3.1$ $\mu \mathrm{m}$ ), which were used as control (Fig. $8)$. The difference between laminin-2 and laminin-8 was highly significant $(p<0.005 ; n=4)$.

\section{Discussion}

Mice lacking the gene for laminin $\alpha 4$ have previously only been described as having abnormalities in vessels and neuromuscular junctions (Patton et al., 2001; Thyboll et al., 2002). We can now conclude that also the peripheral nervous system is strongly affected. Although most largecaliber axons in the sciatic nerve were myelinated, the myelin sheaths were thinner compared with wild-type animals. The most striking defect in the nerves, however, was the formation of bundles of unmyelinated axons. Bundles like these can be seen also in normal nerves, but then before birth, during the so-called "radial sorting process" (Webster, 1975). This process, during which Schwann cells send out cytoplasmic processes into bundles of axons, aims toward establishing a one-to-one relationship between Schwann cells and large axons for myelination to occur. Axons that are destined to remain unmyelinated are meanwhile separately ensheathed by nonmyelinating Schwann cells. Both myelinating and nonmyelinating Schwann cells deposit and organize a basal lamina. The basal lamina is used to mediate changes in cell shape by receptor linkage to the Schwann cell cytoskeleton, and Schwann cells are thus able to extend processes, ensheath axons, and wrap around axons to form myelin (Fernandez-Valle et al., 1997). In the laminin $\alpha 4$ null mouse, groups of axons are aberrantly ensheathed by Schwann cells, so that the axons are not segregated. It is difficult, however, to sort out whether these bundles result from arrest in the process of radial sorting or retraction of Schwann cell processes. Our findings that the ability of Schwann cells to invest axon bundles and myelinate large axons only is affected during developmental myelination, whereas myelination after nerve crush injuries is not affected, indicates that it indeed is the radial sorting that is disturbed. A similar picture can be seen in mice lacking laminin $\alpha 2$, but these mice display more general defects in the basal lamina, compared with the more moderate defects seen in laminin $\alpha 4$ knock-out mice. Considering the possible defect in radial sorting in the laminin $\alpha 4$ mutant mice, it is interesting that the morphology of Schwann cells cultured on laminin-8 differs from what is seen if they are cultured on laminin-2. The ability of Schwann cells to extend processes is likely to be necessary during radial sorting when they segregate axons, and in our study Schwann cells were seen to extend more and longer processes on laminin-8 compared with laminin-2.

We also found that although the myelin thickness in mutant mice was comparable with that in wt mice 6 weeks after a nerve crush injury, the myelin sheaths in mutant mice were thinner compared with wt 5 months after the crush. Thus, the pathological findings are not likely to be solely explained by an error in 
radial sorting, but possibly also a defect in the maintenance of myelin sheaths as well.

A receptor family known to link actinbased cytoskeleton to basal laminas is the integrin family (for review, see Otey and Burridge, 1990; Tarone et al., 2000). Interestingly, the pathology of the laminin $\alpha 4$ null mouse resembles the pathology seen in a mouse in which integrin $\beta 1$ is disrupted in Schwann cells (Feltri et al., 2002), suggesting that integrin $\beta 1$ could be involved in receptor-ligand interaction with laminin-8. In fact, the integrin dimer $\alpha 6 \beta 1$ is a receptor for laminin- 8 (Kortesmaa et al., 2000). Unfortunately, integrin $\alpha 6$ knock-out mice are not possible to examine, because homozygous animals die at birth (Georges-Labouesse et al., 1996). However, it is known that integrins $\alpha 6$ and $\beta 1$ are synthesized in Schwann cells (Feltri et al., 1994) as well as in neonatal and injured spinal motoneurons (Hammarberg et al., 2000a), which all are likely to be in contact with laminin-8-containing basal laminas in peripheral nerves. The integrin $\alpha 6 \beta 4$ receptor is another candidate receptor for laminin-8. This receptor is also expressed in myelin-forming Schwann cells (Einheber et al., 1993). However, this would leave the similar changes in the conditional $\beta 1$ knock-out unexplained. Also, the integrin $\beta 4$ knock-out mouse does not seem to display abnormalities in peripheral nerves (van der Neut et al., 1996).

Recently, the integrin $\alpha 7 \beta 1$ receptor, previously thought to only be expressed in neurons, was found in Schwann cells (Previtali et al., 2003a). Also late neonatal and adult motoneurons express this receptor (Hammarberg et al., 2000a). Genetic inactivation of integrin $\alpha 7$ results in inhibited regeneration after nerve crush injury (Werner et al., 2000) but does not alter peripheral nerve development; particularly, it does not interfere with basal lamina formation, Schwann cell-axon interaction, or myelination (Previtali et al., 2003a). This, in combination with our results indicating that laminin- 8 does not support neurite growth, makes the integrin dimer $\alpha 7 \beta 1$ less likely a receptor for laminin-8. Although the possibility of multiple receptors cannot be ruled out, the most likely integrin receptor for laminin-8 is integrin $\alpha 6 \beta 1$. This is also consistent with the developmental regulation of integrin $\alpha 6 \beta 1$. Integrin $\alpha 6 \beta 1$ is expressed during early embryogenesis when Schwann cells begin to ensheath axons and is thought to play a role in proper Schwann cell-axon interaction (Einheber et al., 1993; Dubovy et al., 2001; Previtali et al., 2001, 2003b; Feltri et al., 2002). In line with this possibility, we found that Schwann cell adhesion to laminin- 8 was blocked by antibodies against integrins $\alpha 6$ and $\beta 1$, whereas adhesion to laminin- 2 was only blocked by antibodies against integrin $\beta 1$. This provides further evidence that Schwann cells indeed interact
Laminin-2
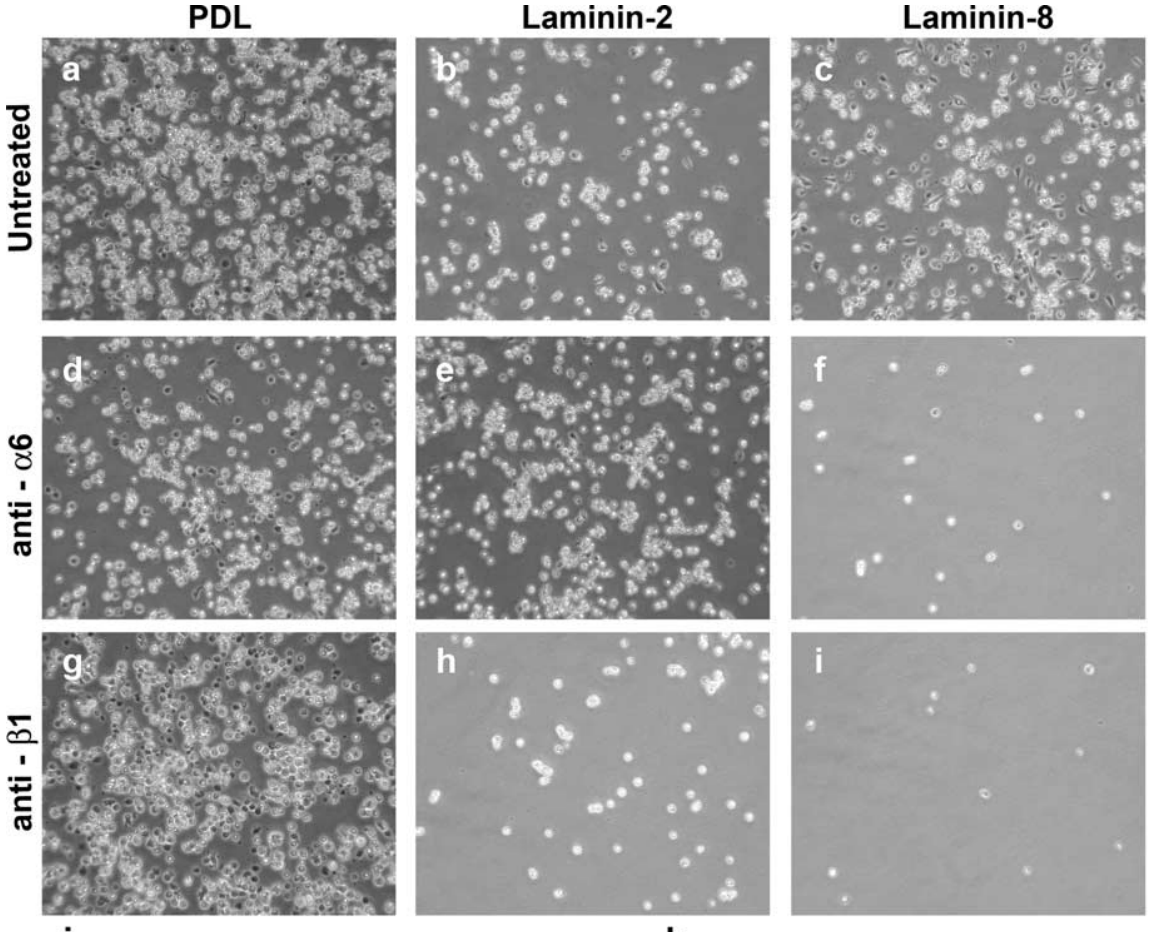

$\mathbf{k}$

Not blocked سAnti integrin $\alpha 6$ 100 Anti integrin $\beta 1$ PAnti integrin $\beta 4$ Echistatin

Figure 6. Schwann cell adhesion and migration on different substrates. Schwann cells adhered strongly to PDL (a), and the attachment was not altered by blocking antibodies against integrin $\alpha 6(\boldsymbol{d})$ or integrin $\beta 1(\boldsymbol{g})$. Schwann cells adhered to a similar

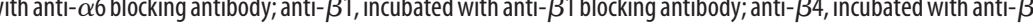
blocking antibody; echistatin, incubation with the RGD-blocking agent echistatin. Migration of Schwann cells was similar on laminin- 2 and laminin- 8 and significantly better on those laminins compared with PDL (k).

with laminin-8 in peripheral nerve endoneurial basal lamina through the integrin receptor $\alpha 6 \beta 1$.

Another receptor that deserves attention in this matter is dystroglycan. Dystroglycan, a component of the dystrophin-glycoprotein complex, is expressed in Schwann cells and known to bind to laminin (Ervasti and Campbell, 1993; Previtali et al., 2003b). Interestingly, the morphology of peripheral nerves of mice in which dystroglycan have been selectively deleted includes polyaxonal myelination and abnormally thin myelin sheaths (Saito et al., 2003), findings that are not prominent in the conditional integrin $\beta 1$ knock-out mouse. Although dystroglycan has not been identified as a receptor for laminin-8 in our experiments, interaction between this receptor complex and laminin- 8 can certainly not be ruled out.

Although motoneurons as well as dorsal root ganglion neurons express integrin receptors that could bind to laminin-8 (Tomaselli et al., 1993; Hammarberg et al., 2000a), the axons are 

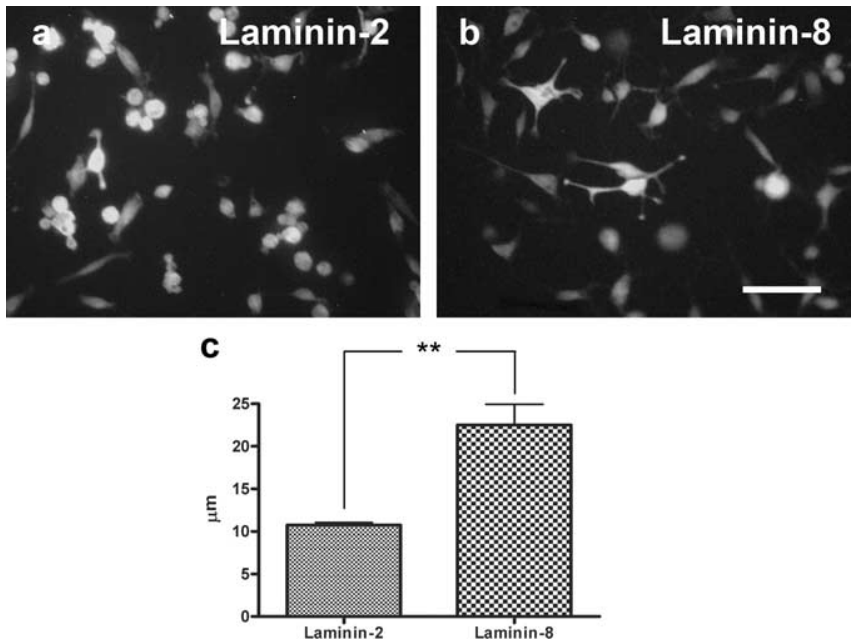

Figure 7. Morphology of Schwann cells cultured on different substrates and labeled with S-100 antibody after $2 \mathrm{~h}$. Schwann cells extended longer processes cultured on laminin-8 $(\boldsymbol{b})$ compared with laminin-2 $(\boldsymbol{a})$. The graph shows the mean length of the longest process of cultured Schwann cells (c). Scale bar, $50 \mu \mathrm{m}$.

\section{Laminin-2}

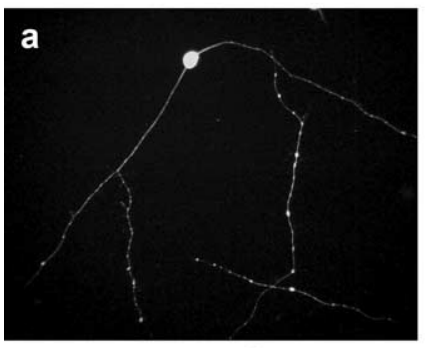

C

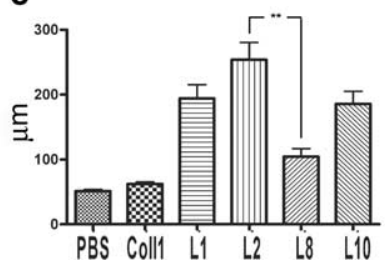

Figure 8. Axon growth on different laminin isoforms $(\boldsymbol{a}, \boldsymbol{b})$. Motoneurons extending neurites on laminin-2 $(\boldsymbol{a})$ and laminin-8 $(\boldsymbol{b})$ are shown. Although neurites grow readily on laminin-2, neurites on laminin-8 are much shorter. The graph shows the mean length of the longest neurite extended on different substrates $(\boldsymbol{c})$. The longest neurites were extended on laminin-2. Also, laminin-1 and laminin-10 proved to support axon elongation. Axon growth on laminin-8 was poor, however, and only slightly better than on collagen-1 or even PBS, which was used as control.

surprisingly unaffected in the laminin $\alpha 4$ mutant mouse. No differences were seen in the axon caliber or the regenerative capacity, as seen in the laminin $\alpha 2$ knock-out or mice with merosin-deficient muscle dystrophy. In our in vitro experiments, it is also clear that, unlike laminin-2, laminin- 8 is not a favorable substrate for neurons to extend their neurite on. Thus, although peripheral axons might bind to laminin-8, the role of this laminin is not to support axonal elongation, as laminin-2 does, but rather to mediate interaction between Schwann cells and axons through the basal lamina and consequently helping the Schwann cell cytoskeleton to assume an appropriate alignment for ensheathment and/or myelination.

In our behavioral analysis, it is evident that the laminin $\alpha 4$ $-/-$ phenotype includes abnormalities in the neuromuscular system. All behavioral data could in fact be explained by the pathological condition found in the peripheral nerves. The peculiar movements of the hindlimbs when holding the mice by the tail, the mild ataxia while walking, and abnormalities seen while the animals are swimming could be caused by a proprioceptive defect. It could also be a result of ephaptic transmission between axons lacking Schwann cell ensheathment. The latter could also explain the tremor found in the mice. Although the behavioral analysis cannot rule out a CNS disorder, we were not able to find any differences in the morphology of CNS white matter between laminin $\alpha 4$ knock-out and wild-type mice. Our results, combined with the fact that the laminin $\alpha 4$ chain has not been found in adult or neonatal CNS, except for the expression in blood vessels (Petajaniemi et al., 2002), makes a CNS disorder unlikely. This is in contrast to what has been found in dy/dy mice, which lack laminin-2 and display a moderate myelination defect in some parts of the CNS (Chun et al., 2003). In peripheral nerves however, the laminin $\alpha 4$ chain is likely present in the basal lamina as the $\alpha$ chain in laminin- 8 (Wallquist et al., 2002). Given the fact that a large part of human cases of peripheral neuropathy remains etiologically unknown, and also that a defect in laminin $\alpha 2$ production is seen in the human disease MDCMD, it may well be that also laminin $\alpha 4$ has a human correlate involving a peripheral neuropathy.

In summary, we have shown that the laminin $\alpha 4$ chain, as a subchain in laminin-8, has an important function in establishing an appropriate relation between axons and Schwann cells in peripheral nerves, that this function is likely to be mediated by the $\alpha 6 \beta 1$ integrin receptor, and that loss of this laminin leads to a neuropathy evident at both behavioral and morphological examination.

\section{References}

Acheson A, Edgar D, Timpl R, Thoenen H (1986) Laminin increases both levels and activity of tyrosine hydroxylase in calf adrenal chromaffin cells. J Cell Biol 102:151-159.

Anton ES, Sandrock Jr AW, Matthew WD (1994) Merosin promotes neurite growth and Schwann cell migration in vitro and nerve regeneration in vivo: evidence using an antibody to merosin, ARM-1. Dev Biol 164:133-146.

Caceres A, Banker G, Steward O, Binder L, Payne M (1984) MAP2 is localized to the dendrites of hippocampal neurons which develop in culture. Brain Res 315:314-318.

Camu W, Henderson CE (1992) Purification of embryonic rat motoneurons by panning on a monoclonal antibody to the low-affinity NGF receptor. J Neurosci Methods 44:59-70.

Chandler CE, Parsons LM, Hosang M, Shooter EM (1984) A monoclonal antibody modulates the interaction of nerve growth factor with PC12 cells. J Biol Chem 259:6882-6889.

Chun SJ, Rasband MN, Sidman RL, Habib AA, Vartanian T (2003) Integrinlinked kinase is required for laminin-2-induced oligodendrocyte cell spreading and CNS myelination. J Cell Biol 163:397-408.

Doi M, Thyboll J, Kortesmaa J, Jansson K, Iivanainen A, Parvardeh M, Timpl R, Hedin U, Swedenborg J, Tryggvason K (2002) Recombinant human laminin-10 (alpha5betalgamma1). Production, purification, and migration-promoting activity on vascular endothelial cells. J Biol Chem 277:12741-12748.

Dubovy P, Svizenska I, Klusakova I, Zitkova A, Houst'Ava L, Haninec P (2001) Laminin molecules in freeze-treated nerve segments are associated with migrating Schwann cells that display the corresponding alpha6beta1 integrin receptor. Glia 33:36-44.

Einheber S, Milner TA, Giancotti F, Salzer JL (1993) Axonal regulation of Schwann cell integrin expression suggests a role for alpha 6 beta 4 in myelination. J Cell Biol 123:1223-1236.

Ericson J, Thor S, Edlund T, Jessell TM, Yamada T (1992) Early stages of motor neuron differentiation revealed by expression of homeobox gene Islet-1. Science 256:1555-1560.

Ervasti JM, Campbell KP (1993) A role for the dystrophin-glycoprotein 
complex as a transmembrane linker between laminin and actin. J Cell Biol 122:809-823.

Feltri ML, Scherer SS, Nemni R, Kamholz J, Vogelbacker H, Scott MO, Canal N, Quaranta V, Wrabetz L (1994) Beta 4 integrin expression in myelinating Schwann cells is polarized, developmentally regulated and axonally dependent. Development 120:1287-1301.

Feltri ML, Graus Porta D, Previtali SC, Nodari A, Migliavacca B, Cassetti A, Littlewood-Evans A, Reichardt LF, Messing A, Quattrini A, Mueller U, Wrabetz L (2002) Conditional disruption of beta 1 integrin in Schwann cells impedes interactions with axons. J Cell Biol 156:199-209.

Fernandez-Valle C, Gorman D, Gomez AM, Bunge MB (1997) Actin plays a role in both changes in cell shape and gene-expression associated with Schwann cell myelination. J Neurosci 17:241-250.

Georges-Labouesse E, Messaddeq N, Yehia G, Cadalbert L, Dierich A, Le Meur M (1996) Absence of integrin alpha 6 leads to epidermolysis bullosa and neonatal death in mice. Nat Genet 13:370-373.

Hammarberg H, Wallquist W, Piehl F, Risling M, Cullheim S (2000a) Regulation of laminin-associated integrin subunit mRNAs in rat spinal motoneurons during postnatal development and after axonal injury. J Comp Neurol 428:294-304.

Hammarberg H, Lidman O, Lundberg C, Eltayeb SY, Gielen AW, Muhallab S, Svenningsson A, Linda H, van Der Meide PH, Cullheim S, Olsson T, Piehl F (2000b) Neuroprotection by encephalomyelitis: rescue of mechanically injured neurons and neurotrophin production by CNS-infiltrating T and natural killer cells. J Neurosci 20:5283-5291.

Hanson Jr MG, Shen S, Wiemelt AP, McMorris FA, Barres BA (1998) Cyclic AMP elevation is sufficient to promote the survival of spinal motor neurons in vitro. J Neurosci 18:7361-7371.

Helbling-Leclerc A, Zhang X, Topaloglu H, Cruaud C, Tesson F, Weissenbach J, Tome FM, Schwartz K, Fardeau M, Tryggvason K, Guicheney P (1995) Mutations in the laminin alpha 2-chain gene (LAMA2) cause merosindeficient congenital muscular dystrophy. Nat Genet 11:216-218.

Henderson CE, Camu W, Mettling C, Gouin A, Poulsen K, Karihaloo M, Rullamas J, Evans T, McMahon SB, Armanini MP, Berkemeier L, Phillips HS, Rosenthal A (1993) Neurotrophins promote motor neuron survival and are present in embryonic limb bud. Nature 363:266-270.

Hughes RA, Sendtner M, Thoenen H (1993) Members of several gene families influence survival of rat motoneurons in vitro and in vivo. J Neurosci Res 36:663-671.

Jones KJ, Morgan G, Johnston H, Tobias V, Ouvrier RA, Wilkinson I, North KN (2001) The expanding phenotype of laminin alpha2 chain (merosin) abnormalities: case series and review. J Med Genet 38:649-657.

Kalcheim C, Barde YA, Thoenen H, Le Douarin NM (1987) In vivo effect of brain-derived neurotrophic factor on the survival of developing dorsal root ganglion cells. EMBO J 6:2871-2873.

Kortesmaa J, Yurchenco P, Tryggvason K (2000) Recombinant laminin-8 (alpha(4)beta(1)gamma(1)). Production, purification, and interactions with integrins. J Biol Chem 275:14853-14859.

Libby RT, Champliaud MF, Claudepierre T, Xu Y, Gibbons EP, Koch M, Burgeson RE, Hunter DD, Brunken WJ (2000) Laminin expression in adult and developing retinae: evidence of two novel CNS laminins. J Neurosci 20:6517-6528.

McGarvey ML, Baron-Van Evercooren A, Kleinman HK, Dubois-Dalcq M (1984) Synthesis and effects of basement membrane components in cultured rat Schwann cells. Dev Biol 105:18-28.

Nakagawa M, Miyagoe-Suzuki Y, Ikezoe K, Miyata Y, Nonaka I, Harii K, Takeda S (2001) Schwann cell myelination occurred without basal lamina formation in laminin alpha2 chain-null mutant $(\mathrm{dy}(3 \mathrm{~K}) / \mathrm{dy}(3 \mathrm{~K}))$ mice. Glia 35:101-110.

Otey CA, Burridge K (1990) Patterning of the membrane cytoskeleton by the extracellular matrix. Semin Cell Biol 1:391-399.

Patton BL, Cunningham JM, Thyboll J, Kortesmaa J, Westerblad H, Edstrom
L, Tryggvason K, Sanes JR (2001) Properly formed but improperly localized synaptic specializations in the absence of laminin alpha4. Nat Neurosci 4:597-604.

Petajaniemi N, Korhonen M, Kortesmaa J, Tryggvason K, Sekiguchi K, Fujiwara H, Sorokin L, Thornell LE, Wondimu Z, Assefa D, Patarroyo M Virtanen I (2002) Localization of laminin alpha4-chain in developing and adult human tissues. J Histochem Cytochem 50:1113-1130.

Piehl F, Ji RR, Cullheim S, Hokfelt T, Lindholm D, Hughes RA (1995) Fibroblast growth factors regulate calcitonin gene-related peptide mRNA expression in rat motoneurons after lesion and in culture. Eur J Neurosci 7:1739-1750

Previtali SC, Feltri ML, Archelos JJ, Quattrini A, Wrabetz L, Hartung H (2001) Role of integrins in the peripheral nervous system. Prog Neurobiol 64:35-49.

Previtali SC, Dina G, Nodari A, Fasolini M, Wrabetz L, Mayer U, Feltri ML, Quattrini A (2003a) Schwann cells synthesize alpha7betal integrin which is dispensable for peripheral nerve development and myelination. Mol Cell Neurosci 23:210-218.

Previtali SC, Nodari A, Taveggia C, Pardini C, Dina G, Villa A, Wrabetz L, Quattrini A, Feltri ML (2003b) Expression of laminin receptors in Schwann cell differentiation: evidence for distinct roles. J Neurosci 23:5520-5530.

Rogers DC, Jones DN, Nelson PR, Jones CM, Quilter CA, Robinson TL, Hagan JJ (1999) Use of SHIRPA and discriminant analysis to characterise marked differences in the behavioural phenotype of six inbred mouse strains. Behav Brain Res 105:207-217.

Saito F, Moore SA, Barresi R, Henry MD, Messing A, Ross-Barta SE, Cohn RD, Williamson RA, Sluka KA, Sherman DL, Brophy PJ, Schmelzer JD, Low PA, Wrabetz L, Feltri ML, Campbell KP (2003) Unique role of dystroglycan in peripheral nerve myelination, nodal structure, and sodium channel stabilization. Neuron 38:747-758.

Sephel GC, Burrous BA, Kleinman HK (1989) Laminin neural activity and binding proteins. Dev Neurosci 11:313-331.

Tarone G, Hirsch E, Brancaccio M, De Acetis M, Barberis L, Balzac F, Retta SF, Botta C, Altruda F, Silengo L, Retta F (2000) Integrin function and regulation in development. Int J Dev Biol 44:725-731.

Thyboll J, Kortesmaa J, Cao R, Soininen R, Wang L, Iivanainen A, Sorokin L, Risling M, Cao Y, Tryggvason K (2002) Deletion of the laminin alpha4 chain leads to impaired microvessel maturation. Mol Cell Biol 22:1194-1202.

Tomaselli KJ, Doherty P, Emmett CJ, Damsky CH, Walsh FS, Reichardt LF (1993) Expression of beta 1 integrins in sensory neurons of the dorsal root ganglion and their functions in neurite outgrowth on two laminin isoforms. J Neurosci 13:4880-4888.

van der Neut R, Krimpenfort P, Calafat J, Niessen CM, Sonnenberg A (1996) Epithelial detachment due to absence of hemidesmosomes in integrin beta 4 null mice. Nat Genet 13:366-369.

Wallquist W, Patarroyo M, Thams S, Carlstedt T, Stark B, Cullheim S, Hammarberg H (2002) Laminin chains in rat and human peripheral nerve: Distribution and regulation during development and after axonal injury. J Comp Neurol 454:284-293.

Webster HD (1975) Development of peripheral nerve fibers. In: Peripheral neuropathy (Dyck PJ, ed), pp 37-61. Philadelphia: Saunders.

Werner A, Willem M, Jones LL, Kreutzberg GW, Mayer U, Raivich G (2000) Impaired axonal regeneration in alpha7 integrin-deficient mice. J Neurosci 20:1822-1830.

Xu H, Christmas P, Wu XR, Wewer UM, Engvall E (1994) Defective muscle basement membrane and lack of M-laminin in the dystrophic dy/dy mouse. Proc Natl Acad Sci USA 91:5572-5576.

Yan Q, Johnson Jr EM (1988) An immunohistochemical study of the nerve growth factor receptor in developing rats. J Neurosci 8:3481-3498. 